Reprinted from the "Proceedings of the Indian Academy of Sciences," Vol. LVI, 1962

\title{
A COMPARISON OF VALUES OF ORGANIC PRODUCTION OBTAINED FROM OXYGEN AND C ${ }^{14}$ METHODS
}

By

R. Raghu Prasad and P. V. Ramachandran Natr 
Reprinted from "The Proceedings of the Indian Academy of Sciences",

Vol. LVI, No. 5, Sec. B, 1962

\title{
A COMPARISON OF VALUES OF ORGANIC PRODUCTION OBTAINED FROM OXYGEN AND $C^{14}$ METHODS*
}

\author{
By R. Raghu Prasad, F.A.Sc., and P. V. Ramachandran NaIR \\ (Central Marine Fisheries Research Institute, Mandapam Camp)
}

Received July 31, 1962

\section{INTRODUCTION}

STUDY of marine photosynthesis has been one of the main concerns of marine biological investigations during recent years. With the introduction of radioactive carbon $\left(\mathrm{C}^{14}\right)$ by Steemann Nielsen (1952) in the measurement of organic production in the sea, this branch of investigation has received considerable fillip. The great sensitivity of this technique has revealed several complex problems regarding factors influencing plant production. However, regarding the interpretation of $\mathrm{C}^{14}$ values there has been much discussion as to whether the method measured gross or net production.

In the oxygen method, dissolved oxygen concentration is influenced by the respiration of the whole community including phytoplankton, zooplankton and bacteria. The 'dark' bottle makes the correction for this respiration. Hence the 'light' and 'dark' bottle method gives gross production. It is also possible from these experiments to measure the "net community production" but not the true net production. But Ryther (1956) remarks that gross production is an intangible quantity, whereas net production is the real production of organic matter which is added to the environment and hence of real concern to the ecologist.

In order to have a proper reconciliation of the values obtained by the oxygen and $\mathrm{C}^{14}$ methods it is essential to have direct comparisons of values of concurrent experiments. But data on these are very scanty and even the available results are mostly for pure cultures.

The authors have been using 'light' and 'dark' bottle method for some time in the study of primary production of the coastal waters of Mandapam. Recently with a consignment of $\mathrm{C}^{14}$ obtained from the International Agency

* Published with the permission of the Director, Central Marine Fisherics Research Institute Mandapam Camp. 
for $\mathrm{C}^{14}$ determination at Charlottenlund, some in situ experiments were also carried out in the inshore waters of the Gulf of Mannar and Palk Bay. Apart from these a few sets of experiments were conductcd in an oceanic environment in the Laccadive Sea. Some of these were concurrent experiments.

\section{RESULTS}

The photosynthetic values from the oxygen experiments have been calculated using a PQ of 1.01 (cf. Prasad and Nair, 1960) and a PQ of 1.25 (Ryther, 1956; Steemann Nielsen--personal communication). Ratios of photosynthetic rates of oxygen to $\mathrm{C}^{14}$ values also have been worked out.

It may be seen from Table I that in most of the experiments conducted in the inshore waters, the ratios are very near to unity. It has been noticed that when phytoplankton is abundant the results are very close. Only in one instance $\mathrm{C}^{\mathbf{1 4}}$ experiment has recorded a higher value than the oxygen method. This may be due to the presence of a larger zooplankton population in the 'light' bottle which would have materially reduced the oxygen value. In this particular experiment, the oxygen in the 'light' bottle was less than the initial value indicating a higher respiratory rate. Disconcertingly large ratios have been obtained in certain cases especially with the oceanic water. But since the values for oligotrophic waters using the 'light' and 'dark' bottle method are questionable these ratios cannot be taken into consideration.

It may be mentioned here that McAllister et al. (1961) recently measured ratios by the two methods and they remark that a corrcct $P Q$ value is of very great importance in marine studies for making an accurate estimate of carbon uptake from oxygen measurements. According to these authors, the difference between the results obtained by the oxygen and $\mathrm{C}^{14}$ methods is mainly due to the non-assessment of the correct photosynthetic quotient for calculating the values of carbon assimilation. It has been the usual practice in oxygen experiments to determine the glucose-carbon equivalent by multiplying the volume of the oxygen produced by 0.536 (or mass of the oxygen produced by 0.375 ). This is on the assumption of a PQ of unity, following the familiar equation:

$$
6 \mathrm{CO}_{2}+6 \mathrm{H}_{2} \mathrm{O} \rightleftharpoons \mathrm{C}_{6} \mathrm{H}_{12} \mathrm{O}_{6}+6 \mathrm{O}_{2}
$$

But Ryther (loc. cit.) remarks that a PQ of unity is largely an experimental artifact and values of 1.1 to 1.3 or higher are normal under natural conditions. Since it is impossible to choose the correct value for routine measurements of natural populations, he suggests a value of 1.25 as more realistic than 1 . $\mathrm{He}$ also noted striking agreement for measurements of photosynthesis with 
TABle I

\begin{tabular}{|c|c|c|c|c|c|c|c|c|c|c|}
\hline \multirow{3}{*}{$\begin{array}{l}\text { Serial } \\
\text { No. }\end{array}$} & \multirow{3}{*}{ Date } & \multirow{3}{*}{ Station } & & \multicolumn{4}{|c|}{ Carbon assimilation as $\mathrm{mg} . / \mathrm{M}^{3} / \mathrm{d}$ ay } & \multirow{2}{*}{\multicolumn{3}{|c|}{ Ratio: $O_{2}$ value $/ C^{14}$ value }} \\
\hline & & & & \multirow{2}{*}{$C^{14}$ Method } & \multicolumn{3}{|c|}{ Oxygen Method } & & & \\
\hline & & & & & $P Q=1 \cdot 01$ & $P Q=1 \cdot 25$ & $P Q=1 \cdot 3$ & $P Q=1 \cdot 01$ & $\mathrm{PQ}=1 \cdot 25$ & $P Q=1 \cdot 3$ \\
\hline $\mathbf{1}$ & $21-12-1960$ & Gulf of Mannar & $\mathrm{s}$ & $265 \cdot 568$ & 389.07 & $315 \cdot 62$ & $302 \cdot 4 I$ & 1.46 & $1 \cdot 19$ & $1 \cdot 14$ \\
\hline 2 & do. & do. & $\mathbf{B}$ & $127 \cdot 717$ & $161 \cdot 65$ & $131 \cdot 15$ & $125 \cdot 66$ & $1 \cdot 27$ & 1.03 & 0.98 \\
\hline 3 & $136-1961$ & Pallk Bay & $\mathrm{s}$ & $24 \cdot 835$ & $62 \cdot 01$ & $50 \cdot 31$ & $48 \cdot 20$ & $2 \cdot 50$ & $2 \cdot 03$ & 1.94 \\
\hline 4 & do. & do. & $\mathbf{M}$ & $27 \cdot 559$ & $31 \cdot 33$ & $26 \cdot 23$ & $25 \cdot 13$ & $1 \cdot 14$ & 0.95 & 0.91 \\
\hline 5 & do. & do. & B & $36 \cdot 316$ & $208 \cdot 29$ & $168 \cdot 99$ & $161 \cdot 92$ & $5 \cdot 74$ & $4 \cdot 65$ & $4 \cdot 46$ \\
\hline 6 & $16-4-1961$ & Androth & $\mathbf{M}$ & $8 \cdot 546$ & $91 \cdot 69$ & $74 \cdot 39$ & $71 \cdot 28$ & $10 \cdot 73$ & $9 \cdot 13$ & $8 \cdot 34$ \\
\hline 7 & do. & do. & B & 5.249 & $133 \cdot 56$ & $108 \cdot 36$ & $103 \cdot 82$ & $25 \cdot 44$ & $20 \cdot 64$ & $19 \cdot 78$ \\
\hline 8 & $|22-4-1961|$ & Minicoy Lagoon & $\mathrm{s}$ & $38 \cdot 224$ & $133 \cdot 56$ & $108 \cdot 36$ & $103 \cdot 82$ & $3 \cdot 49$ & $2 \cdot 83$ & $2 \cdot 72$ \\
\hline 9 & $12-6-1961$ & Palk Bay & $\mathrm{s}$ & $434 \cdot 939$ & $558 \cdot 09$ & $452 \cdot 79$ & $433 \cdot 84$ & $1 \cdot 28$ & 1.04 & $1 \cdot 00^{*}$ \\
\hline 10 & do. & do. & B & $97 \cdot 212$ & $80 \cdot 03$ & $64 \cdot 93$ & $62 \cdot 21$ & 0.82 & 0.67 & \\
\hline
\end{tabular}


oxygen and $\mathrm{C}^{14}$ methods simultaneously with a pure culture of Dunaliella euchlora, with the above PQ. Steemann Nielsen (1952) also had mentioned that the oxygen method must be regarded as giving a greater yield of 33 per cent. than the $\mathrm{C}^{14}$ method and he has put the photosynthetic quotient at 1.33 for this comparative experiments with cultures of Scenedesmus.

For Chlorophyceae and diatoms, most of the $P Q$ values given in the literature are very low, being around 1.05 (cf. Strickland, 1960). With raw sea-water, Sargent and Hindman (1943) obtained the $\mathrm{CO}_{2} / \mathrm{O}_{2}$ ratio of 0.95 which they consider not significantly different from unity and hence they presume the values found by Barker (see Ryther, 1956: Table II) of 1.05 to 1.08 to be characteristic of the whole phytoplankton community. [It may be pointed out here that Rabinowitch (1945) has cautioned, that for photosynthetic quotient $\mathrm{Q}_{\mathrm{p}}=\triangle \mathrm{O}_{2} /-\triangle \mathrm{CO}_{2}$ many authors have designated the inverse ratio - $\triangle \mathrm{CO}_{2} / \triangle \mathrm{O}_{2}$ and that care should be taken in the quotation of numerical results.] Strickland (loc. cit.), who has fully reviewed the measurement of phytoplankton production, interpreted the above low value for raw seawater as due to the reduction of measured PQ brought about by the respiration of zooplankton and bacteria and has suggested an approximate working value of $1 \cdot 2$.

From the above account it may be seen that the general consensus is not in favour of assuming the photosynthetic quotient as unity for estimating the carbon uptake from oxygen experiments. From the data so far obtained from our experiments it is felt that a PQ of little over 1.25 would give comparable results especially in the inshore waters and that when phytoplankton is abundant $\mathrm{C}^{14}$ values approximate gross production. Hence a working value of $1.3\left(1 \mathrm{ml}\right.$. of $\mathrm{O}_{2}=0.412 \mathrm{mg}$. C) is suggested for the estimation of carbon uptake from oxygen experiments.

\section{ACKNOWLEDGEMENT}

The authors are deeply indebted to Dr. S. Jones, Director, Central Marine Fisheries Research Institute, for encouragement. They are also thankful to Shri R. Jayaraman for helpful discussions.

\section{REFERENCES}

\footnotetext{
McAllister, C. D., Parsons, T. R., "Measurements of primary production in coastal sea-water Stepens, K. and Strickland, using a large volume plastic sphere," Limnol. Oceanogr., J. D. $\mathbf{H}$. 1961, 6, 233-58.

Prasad, R. R. and Ramachandran "A preliminary account of primary production and its relation Nair, P. V. to fisheries of the inshore waters of the Gulf of Mannar," Indian J. Fish., 1960, 7, 165-68.
} 
Rabinowitch, E. I.

Ryther, J. H.

Sargent, M. C. and Hindman, J. C.

Steemann Nielsen, E.

Strickland, J. D. H.
.. Photosynthesis and Related Processes, Vol. I, Interscience Publishers, Inc., New York, 1945.

. . "The measurement of primary production," Limnol. Oceanogr., 1956, 1, 72-84.

"The ratio of carbon dioxjde consumption to oxygen evoluticn in sea-water in the light," $J$. Mar. Res., 1943, 5, 131-35.

.. "The use of radioactive carbon ( $\left.C^{14}\right)$ for measuring creanic production in the sea," $J$. Cons. Internat. Explor. Mer., $1952,18,117-40$.

.. "Measuring the production of marine phytoplankton," Bull. Fish. Res, Bd., Canada, 1960, 122, 1-172. 


\section{APPENDIX}

Since this paper was prepared and submitted for publication, the authors came across the note "Primary organic production off Waltair coast" by D. V. Subba Rao and P. N. Ganapati [Curr. Sci., 1962, 31 (6), 242] and felt that there is some confusion in the results reported there and hence this Appendix.

In Table I the organic production values derived from the oxygen technique and expressed in mg. $\mathrm{C} / \mathbf{M}^{3} / 6$ hours do not seem to reconcile with values obtained from the $\mathrm{C}^{14}$ method. If the values given in columns 11-12 under the title "Dark and light bottle tech...." are really the carbon equivalents of oxygen production, as indicated by the unit of expression, then the values seem to be considerably high because of the fact that the standing crop of phytoplankton in terms of numbers of cells per litre or pigment units as observed by the same authors for this region is not very high ( $c f$. Ref. 3 of the note). Data of Galathea station 303, which the authors refer to as a typical coastal station, during the period of primary maximum, shows only about $12 \mathrm{mg} . \mathrm{C} / \mathrm{M}^{3} / 6$ hours at the surface. The values given in column 13 are of course reasonable for the period of secondary maximum which presumably may be the basis of the authors' remark that the magnitude of organic production during the primary peak is more than twice the secondary. But since the authors further state that from the $\mathrm{C}^{14}$ data the total amount of carbon assimilated by algae is calculated employing Doty and Oguri's formula, it is difficult to find out whether the values given in column 13 are the fractions of tracer carbon fixed or total carbon. If the values given in column 13 represent the primary production as $\mathrm{mg}$. C/M $\mathbf{M}^{3} / 6$ hours as indicated by the title, it is actually the total amount of carbon fixed by the algae. So it is not understood how Doty and Oguri's formula has been applied to arrive at the values given in column 14. Besides, it could be seen that for the stations where experiments have been carried out, the total $\mathrm{CO}_{2}$ of sea-water, calculated from the carbonate alkalinity derived from the hydrographical data presented in Table I, does not appear to reach the level of the oceanic waters (i.e., $90 \mathrm{mg}$./1.). 